\title{
Students' Motivations in Choosing English as Additional Course in SMAN 1 Bengkulu
}

\author{
Rama Dahlia \\ English Education Study Program, Language and Art Department, \\ University of Bengkulu

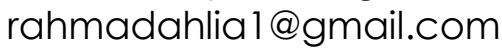 \\ Mulyadi \\ English Education Study Program, Language and Art Department, \\ University of Bengkulu \\ Ladunimulyadi@gmail.com \\ Mei Hardiah \\ English Education Study Program, Language and Art Department, \\ University of Bengkulu \\ mhardiah@unib.ac.id
}

\begin{abstract}
The type of this research is Descriptive Quantitative and Qualitative research. It is aimed to find out the motivation which make students in XII Social 6 choose English as an additional subject course and to find out the highest motivation which make students in XII Social 6 choose English as an additional subject course. The subject of this study is the students in class XII social 6 SMAN 1 Kota Bengkulu. In this research, the researcher collected the data by using questionnaire. Then, the data obtained from the questionnaires will be analyzed using SPSS program. The data concerning subjects' general background as well as their comments will be calculated and presented in percentage. A Likert scale will be used to measure the level and type of subjects' learning motivation. According to table that the researcher used to analyze extrinsic and intrinsic motivation of students in choosing English as additional subject, the researcher got the result that show the extrinsic motivation is the highest reason chosen by the students when they chose English as their additional subject course at school than intrinsic motivation. It can be seen from the calculation scores of students intrinsic and extrinsic motivation that showed the total of mean score for extrinsic motivation is 47.5 and the total mean score for intrinsic motivation is 46.62 . There are several extrinsic motivation from the
\end{abstract}


students, for example the students prepare to learn English because they want to continue the study or get the works, go abroad and want to try to communicate with the foreigner.

Keywords: Motivation, Intrinsic, Extrinsic, Curriculum, Additional course

\begin{abstract}
ABSTRAK
Jenis penelitian ini adalah penelitian deskriptif kuantitaf dan kualitatif. Hal ini bertujuan untuk mengetahui motivasi yang menjadikan siswa di XII Social 6 memilih bahasa Inggris sebagai mata pelajaran tambahan (peminatan) dan untuk mengetahui motivasi tertinggi yang membuat siswa di XII Sosial 6 memilih bahasa Inggris sebagai mata pelajaran tambahan (peminatan). Subjek penelitian ini adalah siswa kelas XII sosial 6 SMAN 1 Kota Bengkulu. Dalam penelitian ini, peneliti mengumpulkan data dengan menggunakan kuesioner. Kemudian, data yang diperoleh dari kuesioner akan dianalisis menggunakan program SPSS. Data mengenai latar belakang umum subyek serta komentar mereka akan dihitung dan disajikan dalam persentase. Skala likert akan digunakan untuk mengukur tingkat dan jenis motivasi belajar mata pelajaran. Menurut tabel yang peneliti gunakan untuk menganalisis motivasi ekstrinsik dan intrinsik siswa dalam memilih bahasa Inggris sebagai subjek tambahan, peneliti mendapatkan hasil yang menunjukkan motivasi ekstrinsik adalah alasan dominan yang dipilih oleh siswa ketika mereka memilih bahasa Inggris sebagai mata pelajaran tambahan mereka di sekolah daripada motivasi intrinsik. Hal ini dapat dilihat dari skor perhitungan motivasi intrinsik dan ekstrinsik siswa yang menunjukkan total skor rata-rata untuk motivasi ekstrinsik adalah 47.5 dan skor rata-rata total untuk motivasi intrinsik adalah 46.62. Ada beberapa alasan ekstrinsik dari para siswa, misalnya para siswa bersiap untuk belajar bahasa Inggris karena mereka ingin melanjutkan studi atau mendapatkan pekerjaan, pergi ke luar negeri dan ingin mencoba berkomunikasi dengan orang asing.
\end{abstract}

Kata Kunci: Motivasi, motivasi dari dalam, motivasi dari luar, kurikulum, Pelajaran tambahan (peminatan)

\title{
INTRODUCTION
}

Knowing that English is not easy, some students were not interested in learning it. However, there are a lot of students trying to know more about English. It is affected by their motivation in learning English. It shows that motivation becomes a key point in learning English. Motivation can influence students' success in learning English. It is supported by McDonough (1983) who states that "the motivation of the students is one of the most important factors influencing success or failure in learning the 
language". Brown (2001) also adds that motivation is a factor that influences the high or low of the goal. It means that motivation deals with encouragement and willingness of the act that cause someone to act directly toward the specific goals to be achieved. It shows that the important of motivation in learning English cannot be separated. With motivation, people are eager to do more. In this education field, motivation makes the students want to learn their subject more from everything and the teachers also try to make the dynamic class.

In learning the target language, there are some types of motivation (Gardner \& Dorney, 2001). They are integrative, instrumental, intrinsic and extrinsic motivation. All types of motivation carry students to achieve certain goals in learning the target language especially English. Those goals can direct them to be students who have good proficiency in English.

Students have many reasons for learning English. It can be simply said that they learn English because they love it or they learn English because it is a school requirement. According to Brophy as cited in Woolfolk (1990), "students' motivation to learn as a students' tendency to find academic activities meaningful and worthwhile and try do derive the academic advantages from those activities". This means that motivated students will make any academic activities become meaningful activities which can improve their skills. When the students are motivated to learn, they will do their academic work seriously and try to do their best out of it. Through the motivation, the students will have an effort when they meet obstacles or failure.

In Indonesia, the government through the Ministry of Education and Culture, develops the 2013 curriculum nationally. The development of the 2013 curriculum is designed to prepare and build Indonesian young generation of a strong future. Indonesian young generation who are civilized, dignified, cultured, characterized, faithful and devoted to God Almighty, noble, healthy, knowledgeable, capable, creative, 
independent, democratic and responsible in guarding the life of the nation and the State.

Senior High School, curriculum is designed to provide opportunities for students or learners to learn based on their interests stated in the "National Education System Law number 20 of 2003 article 12 paragraph (1) point b, stating that students are entitled to appropriate education services with his talents, interests, and abilities." So, the talents, interests, and abilities of students can be served, one of the important policies in the 2013 curriculum is providing opportunities for students or learners to choose groups of subjects of interest (peminatan). The 2013 curriculum structure allows students to make choices in the form of additional course group choices and the choice of subjects between additional course groups or referred to as cross-interest.

The goals of special subject groups; providing opportunities for students to develop their interest in a group of subjects in accordance with scientific interests in university, and developing interest in a particular science or skill. For cross interests, students or learners choose subjects outside of the compulsory subjects and special subjects chosen.

According to the pre-research conducted by the researcher at SMA Negeri 1 Bengkulu, each class was given an additional subject course (Peminatan). The subject chosen is the subject that will be added in the compulsory subject. For science classes, special subjects are offered as follows: sociology, geography, economy and English, while social studies classes, they are offered special subjects as follows: chemistry, physics, biology and English. Each class is only required to choose one subject of specialty that they will choose as a special subject. There is only one class which takes English as a special subject, that is XII Social 6. The researcher only chose SMA Negeri 1 Kota Bengkulu because based on the pre-research that has been conducted, other schools have more than one class that chooses English as a special subject. Furthermore, there are several schools that have no English as a special subject. This is the reason 
why the researcher will conduct the research. The researcher will study what is the motivations that make students of XII Social 6 to choose English as their additional subject course.

\section{Research Question}

The research questions are:

- What are the motivations that make students in XII Social 6 choose English as an additional subject course?

- What is the highest motivation that make student in XII Social 6 choose English as an additional subject course?

\section{Research Objectives}

The research objectives are:

- To find out the motivation which make students in XII Social 6 choose English as an additional subject course.

- To find out the highest motivation which make students in XII Social 6 choose English as an additional subject course.

\section{LITERATURE REVIEW}

A -Schunk, Pintrich, and Meece (2008) who define motivation as the process whereby goal-directed activity is instigated and sustained. Another definition comes from Dornyei (2001) who describes "motivation as the choice of a particular action, the effort of doing something and the persistence with doing it". Dornyei (2001) also states that motivation explains why people decide to do something, how hard they are going to achieve it and how long they are willing to maintain the activity.

B -Moskovsky and Alrabai (2009) state in literature there are different conceptualizations of intrinsic motivation. Intrinsic motivation enhances people's self-concept by engaging them in activities that motivate them. Intrinsic motivation also can be defined in a broader and simpler way: in terms of what people will do without external inducement.

Intrinsic motivation makes the students want to know more about English language. It is not about the language structure, but it can be the literature, culture or society. It is supported by Gardner (1983) who explains 
that "intrinsic motivation is learning a language because the learner wishes to identify himself with or become integrated into the society of target language"

C -Extrinsic motivation is "motivation that is caused by external factors or outside rewards which have nothing to do with the learning situation" (Woolfolk). Wilkins (1972) also supported those arguments by stating:

"A learner is extrinsically motivated when he or she wants to learn language in order to pass examination, to use it in one's job, to use it in holiday in the country, as a change of watching television, because the educational system requires it"

\section{RESEARCH METHOD}

This research was designed as a mixed (descriptive quantitative and qualitative) methods research. Mixed methods research is an approach to inquiry involving collecting both quantitative and qualitative data, integrating the two forms of data, and using distinct designs that may involve philosophical assumptions and theoretical framework (Creswell, 2014). In this research, the researcher studies the Student's Motivation in Choosing English as Additional Course in SMA Negeri 1 Kota Bengkulu. The researcher analyzed and identified the research results using statistical method, by using SPSS version 16 computer program. The data concerning subjects' general background as well as their comments were calculated and presented in percentage.

\section{Research Subject}

The subjects in this study will be 29 students of XII Social 6 at SMA Negeri 1 Kota Bengkulu, consisting of 13 girls and 16 boys.

\section{Technique of Data Collection}

The researcher used several steps to collect the data:

- The researcher will prepare the questionnaire adapted from the Gardner's Attitudes/Motivation Test Battery (AMTB). 
- Before the questionnaire is distributed to the respondents, it needs to be validated. The questionnaire will be validated by the lecturer (Drs.Mazrul Aziz, Dip.TESL.,M.Si., Dr.Dedi Sofyan, M.Hum., Ildi Kurniawan, M.Pd.). The lecturer read and checked each item on the questionnaire.

- The researcher will contact the English teacher as a teacher from elective subject, asking to be able to make a time to distribute the questionnaire in that class.

- The researcher will give questionnaires to each respondent, then the researcher will ask them to fill in the questionnaire based on the instruction.

- Based on the questionnaire that has been filled by students, the data obtained from the questionnaire will be analyzed by using SPSS program.

- The data that has been analyzed by using SPSS program will be presented in the table.

- From the data in the table, the data will present the level of students' motivation in choosing English as an additional subject course.

\section{Technique of Data Analysis}

The researcher conducts the data analysis with the following procedures:

The data obtained from the questionnaires will be analyzed using SPSS program. The data concerning subjects' general background as well as their comments will be calculated and presented in percentage. A Likert scale will be used to measure the level and type of subjects' learning motivation. Such scale will be used in the questionnaire to specify the level of the agreement or disagreement based on the following criteria: 
Table 3.3. Motivation Level

Motivation level based on Best'theory (1970) in ManusakDegang'

(2010:23)

\begin{tabular}{|c|c|}
\hline Mean Range & Interpretation \\
\hline $4.50-5.00$ & Highest Level Motivation \\
\hline $3.50-4.49$ & High Level Motivation \\
\hline $2.50-3.49$ & Moderate Level Motivation \\
\hline $1.50-2.49$ & Low Level Motivation \\
\hline $1.00-1.49$ & Lowest Level Motivation \\
\hline
\end{tabular}

\section{RESEARCH FINDINGS}

Question 1:What are the motivations that make students in XII Social 6 choose English as an additional subject course?

The researcher obtained the data for this research by using the questionnaire as the instrument in this research. In obtaining the data, the questionnaire instrument used in this research was adapted from Gardner (2004), about students' motivation. The researcher also did a validation with three expert judgments from the English study program to avoid mistranslation and mis-understanding about the English words. After the questionnaire instrument has been reviewed, then the researcher distributed the questionnaire on December 10th, 2018. After giving the questionnaire to the sample, the researcher collected and analyzed the data about the category of students' motivation in learning English. The result of the research was described in the table below. It was collected from the questionnaire which consist of 30 item. 
Table 4.1. Descriptive Analysis of Students' Motivation in Learning English (Extrinsic Motivation)

\begin{tabular}{|c|c|c|c|c|c|c|c|}
\hline \multirow[t]{3}{*}{ QI } & \multicolumn{4}{|c|}{ Number of Students Answer } & \multirow[t]{3}{*}{$\mathbf{N}$} & \multirow[t]{3}{*}{ Mean } & \multirow[t]{3}{*}{ C } \\
\hline & STS & TS & $S$ & SS & & & \\
\hline & 1 & 2 & 3 & 4 & & & \\
\hline \multirow[t]{2}{*}{1} & 0 & 0 & 17 & 12 & 29 & 3.41 & Moderate \\
\hline & $0 \%$ & $0 \%$ & $58.6 \%$ & $41.4 \%$ & & & \\
\hline \multirow[t]{2}{*}{2} & 0 & 0 & 18 & 11 & 29 & 3.38 & Moderate \\
\hline & $0 \%$ & $0 \%$ & $62.1 \%$ & $37.9 \%$ & & & \\
\hline \multirow[t]{2}{*}{3} & 0 & 1 & 12 & 16 & 29 & 3.52 & High \\
\hline & $0 \%$ & $3.4 \%$ & $41.4 \%$ & $55.2 \%$ & & & \\
\hline \multirow[t]{2}{*}{4} & 0 & 4 & 16 & 9 & 29 & 3.17 & Moderate \\
\hline & $0 \%$ & $13.8 \%$ & $55.2 \%$ & $31 \%$ & & & \\
\hline \multirow[t]{2}{*}{5} & 0 & 3 & 13 & 13 & 29 & 3.34 & Moderate \\
\hline & $0 \%$ & $10.3 \%$ & $44.8 \%$ & $44.8 \%$ & & & \\
\hline \multirow[t]{2}{*}{6} & 0 & 7 & 19 & 3 & 29 & 2.86 & Moderate \\
\hline & $0 \%$ & $24.1 \%$ & $65.5 \%$ & $10.3 \%$ & & & \\
\hline \multirow[t]{2}{*}{7} & 1 & 1 & 18 & 9 & 29 & 3.21 & Moderate \\
\hline & $3.4 \%$ & $3.4 \%$ & $62.1 \%$ & $31 \%$ & & & \\
\hline \multirow[t]{2}{*}{8} & 1 & 1 & 14 & 13 & 29 & 3.34 & Moderate \\
\hline & $3.4 \%$ & $3.4 \%$ & $48.3 \%$ & $44.8 \%$ & & & \\
\hline \multirow[t]{2}{*}{9} & 0 & 9 & 13 & 7 & 29 & 2.93 & Moderate \\
\hline & $0 \%$ & $31 \%$ & $44.8 \%$ & $24.1 \%$ & & & \\
\hline \multirow[t]{2}{*}{10} & 0 & 2 & 13 & 14 & 29 & 3.41 & Moderate \\
\hline & $0 \%$ & $6.9 \%$ & $44.8 \%$ & $48.3 \%$ & & & \\
\hline \multirow[t]{2}{*}{11} & 0 & 3 & 13 & 13 & 29 & 3.34 & Moderate \\
\hline & $0 \%$ & $10.3 \%$ & $44.8 \%$ & $44.8 \%$ & & & \\
\hline \multirow[t]{2}{*}{12} & 2 & 15 & 9 & 3 & 29 & 2.45 & LOW \\
\hline & $6.9 \%$ & $51.7 \%$ & $31 \%$ & $10.3 \%$ & & & \\
\hline \multirow[t]{2}{*}{13} & 0 & 3 & 13 & 13 & 29 & 3.34 & Moderate \\
\hline & $0 \%$ & $10.3 \%$ & $44.8 \%$ & $44.8 \%$ & & & \\
\hline 14 & 2 & 12 & 11 & 4 & 29 & 2.59 & Moderate \\
\hline
\end{tabular}




\begin{tabular}{|l|l|l|l|l|l|l|c|}
\hline & $6.9 \%$ & $41.4 \%$ & $37.9 \%$ & $13.8 \%$ & & & \\
\hline 15 & 0 & 4 & 15 & 10 & 29 & 3.21 & Moderate \\
\hline & $0 \%$ & $13.8 \%$ & $51.7 \%$ & $34.5 \%$ & & & \\
\hline Total & 6 & 65 & 214 & 150 & - & 47.5 & - \\
\hline
\end{tabular}

QI : Question Item

STS : Sangat tidak setuju (very disagree)

TS : Tidak Setuju (disagree)

S : : Setuju (agree)

SS : : Sangat setuju (very agree)

$\mathrm{N} \quad$ : Number (total of question)

C : Category

In conclusion, from 15 questions made by the researcher to get the data about extrinsic motivation, there are 13 question get "Moderate motivation level", 1 question get "High motivation level" and 1 question get "Low motivation level". It can be seen that dominant students in class XII Social 6 SMAN 1 Kota Bengkulu chose 13 from extrinsic reason why they chose English as additional course in their school. The highest mean score comes from the statement "Saya memilih pelajaran peminatan Bahasa Inggris karena dapat memudahkan ketika saya akan ke luar negeri" which get the mean score 3.52. Then,

As can be seen from the explanation above, almost of the students chose English as their additional subject because they want to prepare themselves to face the foreigner, go abroad, continue their study etc. For more specific, the researcher categorized some extrinsic reason why the students chose English as their additional subject course, they are preparing themselves to go abroad, communicating with other people or foreigner by using English and helping themselves in understanding the terms in social media, website etc which using English. In the table above, the researcher got the total mean of students motivation in choosing English additional subject course reach 47.5. Next, there are the explanation of intrinsic motivation analysis 
Table 4.2 Descriptive Analysis of Students' Motivation in Learning English (Intrinsic Motivation)

\begin{tabular}{|c|c|c|c|c|c|c|c|}
\hline \multirow[t]{3}{*}{$\overline{Q \mathbf{l}}$} & \multicolumn{4}{|c|}{ Number of Students Answer } & \multirow[t]{3}{*}{$\mathbf{N}$} & \multirow[t]{3}{*}{ Mean } & \multirow[t]{3}{*}{ C } \\
\hline & STS & TS & $S$ & SS & & & \\
\hline & 1 & 2 & 4 & 5 & & & \\
\hline \multirow[t]{2}{*}{16} & 0 & 8 & 13 & 8 & 29 & 3.00 & Moderate \\
\hline & $0 \%$ & $27.6 \%$ & $44.8 \%$ & $27.6 \%$ & & & \\
\hline \multirow[t]{2}{*}{17} & 1 & 7 & 12 & 9 & 29 & 3.00 & Moderate \\
\hline & $3.4 \%$ & $24.1 \%$ & $41.4 \%$ & $31 \%$ & & & \\
\hline \multirow[t]{2}{*}{18} & 1 & 4 & 13 & 11 & 29 & 3.17 & Moderate \\
\hline & $3.4 \%$ & $13.8 \%$ & $44.8 \%$ & $37.9 \%$ & & & \\
\hline \multirow[t]{2}{*}{19} & 0 & 3 & 20 & 6 & 29 & 3.10 & Moderate \\
\hline & $0 \%$ & $10.3 \%$ & $69 \%$ & $20.7 \%$ & & & \\
\hline \multirow[t]{2}{*}{20} & 0 & 5 & 18 & 6 & 29 & 3.03 & Moderate \\
\hline & $0 \%$ & $17.2 \%$ & $62.1 \%$ & $20.7 \%$ & & & \\
\hline \multirow[t]{2}{*}{21} & 1 & 10 & 11 & 7 & 29 & 2.83 & Moderate \\
\hline & $3.4 \%$ & $34.5 \%$ & $37.9 \%$ & $24.1 \%$ & & & \\
\hline \multirow[t]{2}{*}{22} & 1 & 7 & 13 & 8 & 29 & 2.97 & Moderate \\
\hline & $3.4 \%$ & $24.1 \%$ & $44.8 \%$ & $27.6 \%$ & & & \\
\hline \multirow[t]{2}{*}{23} & 1 & 2 & 20 & 6 & 29 & 3.07 & Moderate \\
\hline & $3.4 \%$ & $6.9 \%$ & $69 \%$ & $20.7 \%$ & & & \\
\hline \multirow[t]{2}{*}{24} & 0 & 4 & 14 & 11 & 29 & 3.24 & Moderate \\
\hline & $0 \%$ & $13.8 \%$ & $48.3 \%$ & $37.9 \%$ & & & \\
\hline \multirow[t]{2}{*}{25} & 0 & 3 & 17 & 9 & 29 & 3.21 & Moderate \\
\hline & $0 \%$ & $10.3 \%$ & $58.6 \%$ & $31 \%$ & & & \\
\hline \multirow[t]{2}{*}{26} & 0 & 6 & 15 & 8 & 29 & 3.07 & Moderate \\
\hline & $0 \%$ & $20.7 \%$ & $51.7 \%$ & $27.6 \%$ & & & \\
\hline \multirow[t]{2}{*}{27} & 0 & 3 & 14 & 12 & 29 & 3.31 & Moderate \\
\hline & $0 \%$ & $10.3 \%$ & $48.3 \%$ & $41.4 \%$ & & & \\
\hline \multirow[t]{2}{*}{28} & 0 & 2 & 21 & 6 & 29 & 3.14 & Moderate \\
\hline & $0 \%$ & $6.9 \%$ & $72.4 \%$ & $20.7 \%$ & & & \\
\hline \multirow[t]{2}{*}{29} & 0 & 2 & 14 & 13 & 29 & 3.38 & Moderate \\
\hline & $0 \%$ & $6.9 \%$ & $48.3 \%$ & $44.8 \%$ & & & \\
\hline
\end{tabular}




\begin{tabular}{|l|l|l|l|l|l|l|l|}
\hline 30 & 1 & 5 & 13 & 10 & 29 & 3.10 & Moderate \\
\hline & $3.4 \%$ & $17.2 \%$ & $44.8 \%$ & $34.5 \%$ & & & \\
\hline Total & 6 & 71 & 228 & 130 & - & 46.62 & - \\
\hline
\end{tabular}

QI : Question Item

STS : Sangat tidak setuju (very disagree)

TS : :Tidak Setuju (disagree)

S : Setuju (agree)

SS : : Sangat setuju (very agree)

$\mathrm{N} \quad$ : Number (total of question)

C: Category

From 15 questions made by the researcher to get the data about

extrinsic motivation, all of the question got "Moderate motivation level". It can be seen that all of the students in class XII Social 6 SMAN 1 Kota Bengkulu chose 15 intrinsic reason why they chose English as additional course in their school. As can be seen from the explanation above, they have only a little bit motivation comes from inside of themselves. Only several students chose the reason because they enjoy in learning English or to improve the understanding of English component etc.

As general, the researcher categorized some intrinsic reason why the students chose English as their additional subject course, they feel comfortable to learn English, interest to learn more about grammar and other English component etc. But, in the table above, the researcher got the total mean of students' motivation in choosing English additional subject course comes from intrinsic factor reach 46.62. It is lower than total of mean score in extrinsic motivation.

Table 4.3 Motivation Level of Students' Motivation in Choosing English as Additional Course

\begin{tabular}{|c|c|c|c|}
\hline No. & Mean Range & Mean & Question Items \\
\hline 1. & $\begin{array}{c}\text { Highest Level Motivation } \\
(4.50-5.00)\end{array}$ & - & - \\
\hline
\end{tabular}




\begin{tabular}{|c|c|c|c|}
\hline 2. & $\begin{array}{c}\text { High Level Motivation } \\
(3.50-4.49)\end{array}$ & 3.52 & 3 \\
\hline 3. & $\begin{array}{c}\text { Moderate Level } \\
\text { Motivation } \\
(2.50-3.49)\end{array}$ & $2.83-3.41$ & $\begin{array}{c}1,2,4,5,6,7,8,9,10,11,13,16,17,18,19,20,21,22, \\
14,24,25,26,27,28,29,30\end{array}$ \\
\hline 4 & $\begin{array}{c}\text { Low Level Motivation } \\
(1.50-2.49)\end{array}$ & 2.45 & 12 \\
\hline 5 & $\begin{array}{c}\text { Lowest Level Motivation } \\
(1.00-1.49)\end{array}$ & - & - \\
\hline
\end{tabular}

From the table above, there are 30 question divided into five categories after it was answered by 29 students, but the researcher only met the scale criteria to fulfill three categories.

From the explanation of each category above, there are two categories didn't have mean score from quantitative data analysis. The researcher concluded that all students of class XII social 6 in SMAN 1 Bengkulu City have moderate motivation level in choosing English as their additional subject course. It can be seen from the mean score range 2.50 - 3.49 (moderate) was reached from 28 question items. While the mean score range $1.50-2.49$ (low) only gotten from 1 question item and mean score range 3.50 - 4.49 (high) also gotten from 1 question item. In contrast, the mean range score $4.50-5.00$ (highest) and $1.00-1.49$ (lowest) are not reached the mean score from quantitative data analysis. It means that there are no students chose the motivation in choosing English as their additional subject course too high or too low. The tend to chose motivation evenly. So that it affect to the highest and lowest motivation level that have no mean score range.

From the table 4.3 above, it can be concluded that English is one of difficult subject for the students in class XII social 6 SMAN 1 Kota Bengkulu. It can be seen from the explanation above that showed the student have less motivation to learn English comes inside of themselves. It 
means they have less an awareness to learn English to improve their knowledge/skills and enjoy less in learning English. Vice versa the students have high motivation in choosing English as their additional course in their school because they want to prepare themselves to go abroad, continue their study or work and try to speak with the foreigner. All of the reasons included in extrinsic motivation that comes from outside of themselves.

\section{Question 2:What is the highest motivation that make student in XII Social 6 choose English as an additional subject course?}

From the result that has been explained from the previous part, it can be obtained that the highest motivation of students in choosing English as an additional subject is extrinsic motivation. This can be seen from the statement questionnaire item number 3 with statement "Saya memilih pelajaran peminatan bahasa inggris karena dapat memudahkan ketika saya akan keluar negeri". As we can see on data findings, this statement got the mean score of 3.52. It means that this statement chose by almost of the students as the dominant reason or motivation why they chose English as additional subject course. Other reasons why they chose English as additional subject course because they are preparing themselves to go abroad (to continue their study or work), communicating with other people or foreigner by using English and helping themselves in understanding the terms in social media, website etc. which using English.

It can be concluded that most students have motivation in choosing English as an additional subject because they want to go abroad, and by learning English, it can make them easier to reach it. They believe that if they learn English well, they will reach the English skills and knowledge to prepare themselves to go abroad for continuing their study or getting works in the future. In conclusion, this is the highest motivation that make student XII social 6 choose English as an additional subject in their school. 
Generally, almost students in class XII social 6 in SMAN 1 Kota Bengkulu chose English as their additional subject course because the outside reason from themselves. As the researcher explain in findings above, the student interest to learn English more because they want to go abroad to continue their study or works in the future, want to understand the terms, words, phrase or sentences they have met in social media, television or other communication media, want to improve their knowledge or skills so that if they meet the foreigner or other people, they are ready to use English to communicate with them. Those reason are included in extrinsic motivation that comes from outside of the students want.

In contrast with extrinsic motivation, the students have lower motivation comes from inside of themselves. Although several statements reach high mean score, it is not enough to explain that the student have the big motivation to learn English inside themselves. As the finding explanation above, there are only some students agree with the statement if they chose English as additional English because they want to learn it seriously, to enjoy the learning activities or to improve their knowledge about English component like grammar etc.

\section{Discussion}

In this part, the researcher will explain more about the result of the study that has been done. It will consist of the related theory to this research and how the relation of this research with some previous studies.

Motivations were categorized into two parts in general, they were intrinsic motivation and extrinsic motivation (Dornyei: 2001). Based on the data presented in finding above, it provides the information that most of the students have motivation in learning English by their extrinsic motivation. Intrinsic motivation is a type of motivation that was derived from outside of the students. From the result of the research, the motivation that make students choosing English as additional subject course and highest motivation which lead them to choose English as an 
additional subject is extrinsic motivation because it makes them easier to go abroad and several other question items that represent intrinsic and extrinsic motivation that students choose as motivations that make them choose English as additional course.

From those reason the students will drive to make an effort to achieve their reasons and their goals in learning English. Furthermore, from the data presented above, it can be concluded that the students of class XII social 6 SMAN 1 Bengkulu city had extrinsic motivation as the dominant motivation in choosing English as additional subject. There are some factors that influence the student extrinsic motivation such as the students were motivated to learn English because they want to achieve their goals, for example: they want to learn English as International language, they want able to speak English with foreigners etc. Furthermore, from the calculation scores of students intrinsic and extrinsic motivation above, the researcher found that the total mean score for extrinsic motivation is 47.5 and the total mean score for intrinsic motivation is 46.62. It explains that the students of class XII social 6 SMAN 1 Bengkulu city have higher extrinsic motivation than intrinsic motivation in choosing English as additional subject. This is good for the student and teacher in teaching and learning process. Because, motivation is the one of important thing which is affects students' attitude and achievement. In this finding, the students have good motivation, so it will be useful for the teacher to bring the student to be successful in learning English.

From the explanation above, it can be obtained that extrinsic motivation seems to be more becoming the students' motivation in choosing English as an additional subject rather than intrinsic motivation. Related to some previous studies, a study conducted by Kinanti (2016) supports this study. She conducted the study in SMP BOPKRI 1 Yogyakarta. The result of her study revealed that students have extrinsic motivation in learning English. The students were learning English because they did not only want to know the English language, but also learn the English culture 
and English literature. Then, for the students, English can make them meet many people in the world.

Another research was conducted by Fachraini in 2017 entitled "An Analysis of Students' Motivation in Studying English (A Survey Study at UIN Ar-Raniry Banda Aceh)". She investigated about students' motivation in learning English, whether they had intrinsic or extrinsic motivation. Samples of this research were 142 English students from first, third, fifth and seventh semesters. The results of this research showed that the total mean score of extrinsic motivation is higher than the total mean score of intrinsic motivation. It means that English students at UIN Ar-Raniry had higher extrinsic motivation than intrinsic motivation in learning English. In other words, the motivation to learn English that comes from outside students was bigger than the motivation comes from inside students itself.

Finally, by using Likert scale adapted from Gardner's theory, the researcher found the dominant and the least student's motivation in learning English is from extrinsic or outside of the students itself. The dominant motivation found in this research can be seen from the students' willingness for learning English to go abroad with the reason to know more about another country or destination to study, students exchange or travelling in the future. Besides that, they also have the motivation to communicate with other people or foreigner by using English and it will help themselves in understanding the terms in social media, website etc. which using English.

In conclusion, based on the research questions, the researcher found that the intrinsic and extrinsic motivation have the same influence to be the reason why the students chose English as additional subject course in their school. After the researcher analyzed the research result deeply, the researcher found the differences between two motivation types above were the students' motivation level in choosing English as additional subject course by using Likert scale adapted from Gardner's theory. It sees that the extrinsic motivation got the highest mean score 
than intrinsic motivation. It means that some factors why they chose English as their additional subject course such as their willing to go abroad, to get the highest English test score and to communicate with others by using English are the dominant reason more than their willing to learn English seriously, to enjoy the learning activities or to improve their knowledge about English component like grammar etc.

\section{CONCLUSION}

According to the previous discussions, after all the researcher can draw some conclusions in the following:

This research is conducted to find out the type of students' motivation and to analyze the dominant reason of students' motivation in choosing English as additional subject in their school. As the researcher said before, the subject of this research is students of XII Social 6 at SMA Negeri 1 Kota Bengkulu. The students' motivations were divided into two categories based on the theory from Dornyei (2001) they are extrinsic and intrinsic motivation.

The first category is extrinsic motivation. From the findings and discussion, this type of motivation reach total of mean score 47.5. The highest mean score comes from statement explained that the students' motivation in choosing English as their additional subject course in their school because they want to prepare themselves to get a scholarship and go abroad (continue their study or get works) in the future.

The second category is intrinsic motivation. From the findings and discussion, this type of motivation reach total of mean score 46.62. The highest mean score comes from statement explained that the students' motivation in choosing English as their additional subject course in their school because they still have an awareness make ends meet like to understand English used in the movie, drama etc, or to prepare themselves in English test so that they can get good score or success in answering difficult English questions. In conclusion, the researcher 
categorized some intrinsic reason why the students chose English as their additional subject course, they feel comfortable to learn English, interest to learn more about grammar and other English component etc.

\section{Suggestions}

In this subchapter, the researcher would like to give some suggestions as follows:

\section{Practical Contribution}

a. For the lecturer, this research will give feedback and information in teaching and learning about students' motivation in English study program. The lecturer can motivate the students more, so it might improve the quality of the students, and they want to be a great teacher in the future.

b. For the students, this research will be useful for is students of XII Social 6 and other students at SMA Negeri 1 Kota Bengkulu because this study conducted to know the information about their motivation in their learning English. When they know about their motivation in their learning English, they would change and improve their motivation by themselves.

c. For the future researcher, this research can be used as a reference to conduct a research with the same topic. The future researcher can continue this study to investigate the reason of extrinsic or intrinsic motivation. The future researcher also can develop the research such as do a correlation with the other variable or conduct the research with the different subject or location. Furthermore, the future research can develop the research with different aspect with the same theory of students' motivation. 


\section{Theoretical Contribution}

This research is expected to help in finding out the students' motivation in learning English had by is students of XII Social 6 at SMA Negeri 1 Kota Bengkulu.

\section{REFERENCES}

Arviana, V. (2008). Students' Integrative and Instrumental Motivations in Learning English(A Study on the First Year Students of the Vocational School Number 2 Kepahyang). Unpublished thesis of Bachelor (S1). Universitas Bengkulu

Beck, R. C. (1978). Motivation: theories and principles. NJ: Prentice Hall, Inc.

Bhoje, G. (2015). The importance of motivation in an educational environment. India: Laxmi Book Publisher.

Covington, M.V., \& Mueller, J.K. (2001). Intrinsic versus extrinsic motivation:

An approach avoidance reformulation. Education

PsychologyReview, 13.

Deci, E. L., \& Ryan, R. M. (1985). Intrinsic motivation and self-determination in human behaviour. NY: Plenum Press.

Dornyei, Z. (2001). Motivational strategies in the languageclassroom. Cambridge: Cambridge University Press.

Fachraini, Siti. (2017). An Analysis of Students' Motivation in Studying English (A Survey Study at UIN Ar-raniry Banda Aceh). Aceh: UINAr-raniry

Frith, C. (2001). Motivation to learn. Saskatchewan: University of Saskatchewan.

Harmer, J. (1992). The practice of English language teaching $\left(3^{\text {rd. }}{ }^{\text {Ed.). }}\right.$. London: Pearson EducationLtd

Lai, E. (2011). Motivation: a literature review. Retrieved from http://images.pearsonassessments.com/images/tmrs/Motivation_Re view_fi nal.pdf on October 11, 2015.

Lepper, M., \& Hodell, M. (2001). Intrinsic motivations in the classrooms. San Diego: AcademicPress.

Moskousky, C., \& Alrabai, F. (2009). Intrinsic motiva/tion in Saudi Learners of English as a foreign language. The open Applied Linguistic Journal, 21:1- 10.

Pintrich, P.L., \& Schunk, D.H. (1996). Motivation in education: Theory research and applications. Englewood Cliffs, NJ: Practice Hall.

Pratiwi, D.F., (2015). The Learning Motivation and Preferred learning Activities of Successful Students of English Education Study Program 
at Universitas Bengkulu. Unpublished thesis of Bachelor (S1).

Universitas Bengkulu

Gardner, R. C., Ph.D. 2004. Attitude/Motivation Test Battery: InternationalAMTB Research Project. The University of Western Ontario,Canada. (English version).

Ryan,R.M., \& Deci, E.L. (2000). Intrinsic motivations and extrinsic motivations: classic definitions and new directions. Contemporary Educational Psychology, 25:54-67

Sadirman. (2006). Interaksi dan motivasi belajar mengajar. Jakarta: Rasa GrafindoPersada.

Schunk, D. H., Pintrich, P. R, \& Meece, J. L. (2008). Motivational in education: theory, research, and applications. Upper Saddle River, NS: Pearson Educati 